\title{
ARTICLE
}

\section{Article 8 of the Human Rights Act 1998 and intellectual disability}

\author{
Martin Curtice \& Juli Crocombe
}

\begin{abstract}
Martin Curtice is a consultant in old age psychiatry. He obtained a Master of Laws with Distinction in Mental Health Law in 2003 and has an interest in mental health law and the Human Rights Act. He sits on the Royal College of Psychiatrists' Special Committee on Human Rights and has written extensively on human rights mental health law. Juli Crocombe is a consultant in forensic learning disability psychiatry. She obtained a Master of Laws with Distinction in Mental Health Law in 2001 and has an interest in mental health law and the Human Rights Act. She gave oral evidence to the scrutiny committee for the draft Mental Health Bill and is a member of the advisory group to the All Party Parliamentary Group on Autism.
\end{abstract}

Correspondence Dr Martin Curtice, Hollyhill Unit, Rubery Lane, Rubery, Birmingham B45 8GD, UK. Email:mjrc@ukonline.co.uk

\begin{abstract}
SUMMARY
Various UK reports have identified issues of poor health and social care for people with an intellectual disability. Such reports emphasise the vital importance of addressing human rights issues in the future to improve and address shortcomings in such care. Article 8 of the European Convention on Human Rights affords protection for private and family life, and applies irrespective of whether someone has the capacity to make such decisions affecting their life. This in particular is important for people with an intellectual disability. Compared with the rest of the Convention, there has been relatively more case law pertaining to Article 8. This review considers Article 8 case law involving people with an intellectual disability in the areas of community care, accommodation, day centres, lifting and hoisting, sexual relations, marriage and education. In doing so, it demonstrates the varied application and core principles for use of the Article in clinical practice and decision-making.
\end{abstract}

\section{DECLARATION OF INTEREST}

None.

The Human Rights Act 1998 incorporates into UK law most of the rights and freedoms set out in the European Convention on Human Rights. All of the rights set out in the Convention equally apply to people with an intellectual disability (also known as learning disability in UK health services) and physical disability. However, compared with the rights contained in the Convention, there is a plethora of case law pertaining to Article 8 and people with intellectual disabilities.

Article 8 of the Human Rights Act is a qualified right to respect for private and family life (Box 1). Courts will initially see whether an interference corresponds to any of the areas outlined in the first paragraph. If so, the second paragraph is analysed to ascertain whether the interference can be justified under any of the exceptions outlined. In relation to healthcare this usually pertains to the protection of health or the rights and freedoms of others, as has been described in this journal (Curtice 2009a) and elsewhere (Curtice 2009b,c).

Being a qualified right, Article 8 has become one of the most dynamically interpreted provisions of the European Convention on Human Rights and can be applied in myriad ways (Curtice 2009a,c). This article reviews the application and interpretation of Article 8 in case law relating to people with intellectual disabilities and examines its implementation in clinical practice.

\section{Community care}

\section{Rachel Gunter (by her litigation friend and father Edwin Gunter) v. South Western Staffordshire Primary Care Trust [2005]}

This case, in considering whether to provide a residential or home-based package of care for a severely disabled young woman, concluded that the primary care trust assessing her care must give proper weight to her Article 8 rights. (This is not specifically an intellectual disability case, but the central tenets can easily apply to such cases.) During her childhood, she sustained two strokes following high-risk surgery for a brain tumour. These damaged more than $70 \%$ of her brain, rendering her blind and inducing diabetes insipidus. Whereas it was common ground that she needed constant, qualified, one-to-one nursing care, the Court reviewed a dispute between the parents and the primary care trust as to whether her long-term care should be in a residential home or through 24-hour nursing care in the family home.

The primary care trust preferred the residential home option owing to: (a) cost; (b) the perceived risks to Rachel if a life-threatening emergency (which could occur at any time) arose; and (c) the greater social interaction possible in a residential setting. Both Rachel (who was assessed by a doctor

BOX 1 Article 8 of the Human Rights Act 1998

1 Everyone has the right to respect for his private and family life, his home and his correspondence.

2 There shall be no interference by a public authority with the exercise of this right except such as is in accordance with the law and is necessary in a democratic society ... for the protection of health or morals, or for the protection of the rights and freedoms of others. 
as being able to express her views on where she wanted to live but lacked capacity to enter into other decisions) and her parents wanted care in the family home.

This case went to judicial review but the presiding judge considered this an "unsatisfactory means of dealing with cases such as this where there are judgments to be made and factual issues may be in dispute. At best, it can identify failures to have regard to material considerations and hence a need for a reconsideration' (para. 19). Only rarely would it result in mandatory orders to the public authority that had the responsibility for making the relevant decision. The judge remitted the decision back to the primary care trust to reconsider, emphasising the importance of Article 8 when considering community care (Box 2).

\section{Katie Collins v. The United Kingdom (2002)}

This case provided an analysis of Article 8 in a decision to move an adult with intellectual disabilities (who had been promised a 'home for life') from a long-stay hospital into the community.

The applicant was aged 36 . She had microcephaly, autism and had a mental age of about $4 \frac{1}{2}$ years. In 1990, she was moved into a purposebuilt complex for severely disabled adults within a hospital (Long Leys Court, Lincoln, UK). The parents had been given assurances that Katie would be provided with a 'home for life' at Long Leys. In 2000 , the local health authority issued proposals which meant that Katie (and other residents) would be transferred to social care in the community. The parents complained that the health authority had reneged on its promise of a 'home for life', that the applicant would be adversely affected by the change to her environment and that the applicant herself was adamant that she wished to remain at Long Leys.

The applicant complained that the decision to remove her from Long Leys was an unjustified interference with her Article 8 rights. The key issue was whether this interference could be justified by the health authority under Article 8(2). The Court held that the health authority was indeed interfering with the applicant's Article 8(1) right to respect for her private life, but this interference could be justified under Article 8(2). The procedures followed were 'in accordance with the law', with the legitimate aim of furthering the applicant's welfare 'and thus of the protection of the rights of others'. The move was also deemed 'necessary in a democratic society' on the basis that proper consideration had been given to the applicant's interests and that the overall decision had been taken out of concern for her welfare.
BOX 2 Community placements: salient points from the Rachel Gunter case
- Cost was clearly a relevant factor and 'perfection' could not always be achieved - financial considerations are material

- 'Health Authorities never have enough money to provide the level of services which would be ideal' (para. 19) - but this did not mean that a disabled person should receive care that did not properly meet their needs

- Although Article 8 had been alluded to by the primary care trust in a decisionmaking meeting, its real impact did 'not seem to have been appreciated', and in reconsidering the decision the primary care trust should give it 'its proper weight', which was 'considerable' (para. 21)
- Removing Rachel from her home would have clearly interfered with her rights under Article 8(1) to respect for her family life. If such interference were to be lawful, it would have to be justified as 'proportionate' under Article 8(2). Cost was a factor that could 'properly be taken into account', but the primary care trust needed also to consider the improvement in Rachel's condition at home, the obvious quality of her life within her family environment and her expressed views. These were important factors that suggested that to remove Rachel from her home required 'clear justification'

(Rachel Gunter (by her litigation friend and father Edwin Gunter) v. South Western Staffordshire Primary Care Trust [2005])
This included appropriate consideration of the weight of the applicant's views and included legal advice as to the status of a 'home for life' promise - a 'home for life' did not necessarily mean at a particular hospital or place of residence, but rather that the needs of individuals were met appropriately. The applicant's family argued that a move would be harmful because the applicant reacted badly to a change in routine, but the evidence from a consultant psychiatrist suggested that the impact on the residents would be beneficial in many areas.

On the 'home for life' issue the Court noted that, although it was 'highly regrettable' that a promise had apparently been made that misled the applicant and her family, this assurance was not found to be a legally binding obligation on the health authority to comply with the applicant's personal preferences. The Court did not find this an 'unreasonable or arbitrary conclusion' and opined that, given the 'vagaries of future circumstances', a statement made in 1990 could not realistically have been expected to guarantee an indefinite placement for the applicant, whether for 'practical, medical or other reasons'. The Court found the health authority's decision to be proportional, having given proper consideration to her interests and welfare (see also (1) $\mathrm{CH}$ (by the Official Solicitor as litigation friend) and (2) $\mathrm{MH}$ (by the Official Solicitor as litigation friend) v. Sutton $\mathcal{E}$ Merton Primary Care Trust [2004], where Article 8 was again pivotal in assessing the best interests of people with severe intellectual disability who had similarly been assured of a 'home for life' when their long-stay hospital was to be closed). 


\section{Accommodation}

\section{$R$ (on the application of Hughes) v. Liverpool City} Council [2005]

This case involved a young man born in 1985 who had cerebral palsy, severe intellectual disability and poorly controlled epilepsy. His mother cared for him from birth with help from outside agencies. They lived in a three-bedroom, semi-detached house that was acknowledged as being unsuitable for the man's needs. The claimant applied for judicial review of the local authority's failure to adequately assess his needs for specially adapted accommodation as provided by the National Assistance Act 1948 (Section 21 - Duty of local authorities to provide accommodation). It was claimed that his Article 8 rights were infringed because the local authority's response had been so inadequate as to be unlawful and had breached the statutory duties owed to him.

The judge opined that 'honest but unavailing attempts' had been made to find alternative accommodation and the Article 8 claim failed. He noted that the applicant's private and family life had been protected and promoted principally by the efforts of his mother (while acknowledging that the burden on her had been 'very great, even intolerable'). Owing to the mother's efforts, the impact of the local authority's shortcomings on the claimant's private and family life had been 'reduced to a level' at which his Article 8 rights had not been infringed. The judge concluded that the limitations imposed on the claimant's enjoyment of private and family life stemmed from his own condition. He pertinently noted that the situation regarding future care could well change, whereby Article 8 rights could become infringed (for example, if the mother was unable to continue to provide care and her efforts were not adequately substituted by the local authorities).

\section{Bernard v. London Borough of Enfield [2002]}

This is not an intellectual disability case but the issues from this case regarding a disabled woman could easily apply to people with an intellectual disability. The woman had experienced a stroke and hemiplegia had left her dependent on an electric wheelchair. She lived with her husband and six children. Following mortgage arrears, the family was forced to move from its fully adapted house and took a tenancy in an unadapted property. When the tenancy expired they applied to the local authority for accommodation. The accommodation provided was assessed as being unsuitable because Mrs Bernard could not use her wheelchair or access the first floor; it was not adaptable. Although the local authority accepted that it was under a duty to provide suitably adapted accommodation under Section 21 of the National Assistance Act, there ensued a period of 20 months during which they did not comply with their duty or act on Social Services' recommendations. The claimants asserted that this delay breached their Article 8 rights.

The Court recalled that Article 8 may require public authorities to take positive measures to secure respect for private or family life, not to merely abstain from interference (Markcx $\mathrm{v}$. Belgium [1979]). That is, there are negative and positive obligations inherent in effective respect for private or family life. Indeed, what was at issue in this case was a complaint not of action but of inaction by the state.

On the interaction between the National Assistance Act and the Human Rights Act, the Court observed that not every breach of duty under Section 21 of the National Assistance Act would result in a breach of Article 8 - the Article does not require the state to provide every citizen with a house. However, those entitled to care under Section 21 are a particularly vulnerable group. Positive measures must be taken to enable them to enjoy, so far as possible, a normal private and family life.

The Court noted that whether a breach of the National Assistance Act also resulted in an infringement of Article 8 rights would depend on all of the circumstances of the case. Applying these principles, the local authority was under an obligation to take positive steps to enable the claimants and their children to lead as normal a family life as possible, for example: being able to move around a home to a greater degree (not being confined to a shower chair for most of the day); playing a part in looking after her children; and having privacy. The Court concluded that the failure of the local authority to act on assessments indicating that appropriate accommodation should be found meant that it was virtually impossible for the claimants to have any meaningful private or family life and this breached both the National Assistance Act statutory duty and Article 8. The claimants were awarded $£ 10000$ in compensation ( $£ 8000$ for the woman; $£ 2000$ for the husband).

\section{Day centres}

\section{$R$ (on the application of $J$ and others) $v$. Southend} Borough Council [2005]

In this case the High Court found the decision of a local borough to restrict day-centre services to just local residents did not breach the Article 8 rights of residents of a neighbouring local authority area who had been long-time users of the same centre. The case was brought on behalf of several 
adults with intellectual disabilities who had, for a long time (more than 20 years for three of the claimants), been attending a day centre in Southend, UK, although they lived in a different local authority area (Essex). Southend Borough Council had taken the decision to close its only other day centre to free up funding for modernising its intellectual disability services. In doing so it wanted to reserve the places in the remaining day centre for its own residents. The attendees from Essex challenged this decision.

The judge accepted that the withdrawal of access to the day centre in Southend would affect the Essex attendees' Article 8(1) rights, because it would disrupt established friendships and relationships. However, he did not accept that these rights would be breached, because:

- despite the relocation of services, steps were being taken to enable and facilitate existing friendships to continue;

- it was not necessary to consider whether Southend Council's actions fell to be analysed under the negative obligation to refrain from interference with individuals' private lives or the positive obligation to take appropriate steps to promote respect for individuals' private lives. The proposals clearly had a legitimate aim (to improve services overall) and the action that had taken place was proportionate. Public authorities were entitled to take policy decisions that 'strike a fair balance without the necessity to consider individual circumstances' (para. 56); and

- the beneficial effects of modernised services should not be forgotten. The future held open 'a scope for new relationships' and 'a new dimension in their private life', along with 'a sufficient retention of their past private life so as to limit the impact of change' (para. 56).

\section{Lifting and hoisting}

\section{$R$ (on the application of (1) $A,(2) B$ (by their litigation friend the Official Solicitor), (3) $X$ and (4) Y) v. East Sussex County Council \& the Disability Rights Commission (interested party) [2003]}

This case involved two sisters with profound physical and intellectual disabilities. They were looked after full time by their mother and stepfather in the adapted family home. Even the simplest of physical movements, such as getting in or out of bed or the bath, required them to be moved or lifted. A dispute evolved between the parents and East Sussex County Council over whether and to what extent the moving and lifting should be done manually in some instances (the parents' preference) or by using appropriate handling equipment (the Council's preference). The Court was asked to determine whether the sisters had a right under the European Convention on Human Rights to be lifted manually rather than through the use of equipment.

The judge noted that in certain circumstances a failure to lift manually might threaten the women's absolute rights under Article 2 (the right to life) or Article 3 (freedom from inhuman or degrading treatment). Manual lifting would be required in some circumstances, regardless of the impact on the carers (for example, in the case of a fire or other life-threatening situations, or where the sisters might otherwise be left in an undignified or distressing situation for an unacceptably long period of time).

There could also be competing Article 8 rights of those concerned, for example, the sisters' need to have their human dignity maintained and the carers' rights not to suffer avoidable injury. The judge noted 'a fair balance between competing interests must be struck' and factors to be taken into account included: the possible methods of avoiding or minimising the risk of harm to the carers; the context of the particular lift, such as its frequency; the likelihood and severity of the risk to the carer; and the impact on the disabled person.

The judge made pertinent observations in relation to Article 8 and people with disabilities. He opined that the right to respect for one's physical and psychological integrity could be divided into two distinct 'equally important concepts' - human dignity and the right to participate in the life of the community. On human dignity he noted that, although the phrase is not specifically mentioned in the European Convention on Human Rights, 'it is surely immanent in Article 8' and is 'in truth the core value' of society (para. 86). He concluded that an 'enhanced degree of protection' (para. 93) would be called for when the human dignity at stake was that of an individual who was so disabled as to be dependent on others for even the most basic aspects of daily living - the more severe the disability and the harder it was for the individual to participate effectively in the community, the more weight should be placed on the importance of any activities in which they could participate.

The judge held that the Convention rights of both the disabled individuals and of their carers must be considered when deciding whether it is appropriate to lift disabled individuals manually or using a hoist - the rights of neither side automatically 'trumping' the other's. As in so many other areas where law and social policy intersect, the judge observed that 'context is everything'. In this case it was for the Council and not the Court to evaluate that context. 


\section{Sexual relations and marriage}

Local Authority X v. (1) MM (by her litigation
friend the Official Solicitor) (2) KM [2007]

This case provided an in-depth review of the capacity to consent to sexual relations, Article 8 being 'central' to the case. It involved a woman born in 1968 who had a moderate intellectual disability and paranoid schizophrenia; she was a vulnerable adult known to services. Her partner of 15 years had been diagnosed as having psychopathic personality disorder. It was alleged that he had undue influence on her and encouraged her to leave supported accommodation and disengage from psychiatric services. In response to fears that he was proposing to take her away, the local authority obtained interim injunctions stating that M lacked capacity to decide where she should reside and with whom she should associate. Various issues of capacity were assessed by a consultant psychiatrist, who concluded that M lacked capacity to litigate, to decide where she should live and with whom, to decide with whom she should have contact, to marry and to manage her financial affairs. However, she was assessed as having the capacity to consent to sexual relations.

The test used for assessing capacity to consent to sexual relations was from $X$ City Council v. $M B$, $N B$ and $M A B$ (by his litigation friend the Official Solicitor) [2006]. It asks whether the person has:

- sufficient knowledge and understanding of the nature and character - the sexual nature and character - of the act of sexual intercourse;

B0X 3 Article 8 and sexual relations

- Article 8 recognises that sexual activity is a most intimate aspect of private life (Dudgeon v. The United Kingdom (1981))

- Sexual activity involves fundamental values and essential aspects of private life ( $X$ and $Y v$. The Netherlands (1985))

- The private life protected by Article 8 encompasses choice about personal and sexual relationships with others (Pretty $v$. The United Kingdom (2003))

- Article 8 requires respect for an individual's sexual activities (Pretty $v$. The United Kingdom (2003))

- Unwanted or inappropriate sexual attentions will involve an interference with the physical and moral integrity, which is itself protected by Article 8 ( $X$ and $Y v$. The Netherlands (1985))

- By virtue of Article 8 , states may be under a positive duty to prevent unwanted or inappropriate sexual attention, especially for those who lack capacity. For example, where a young woman with an intellectual disability had been sexually assaulted, the state was held to be in breach of its positive obligations, having failed in its duty to provide an effective criminal remedy to ensure deterrence in relation to sexual assault $(X$ and $Y$ v. The Netherlands (1985))

- Under Article 8, the state is entitled to control even seemingly consensual sexual acts in private where it is necessary to 'safeguard... against exploitation and corruption... those who are specially vulnerable because they are young, weak in body or mind, inexperienced, or in a state of special physical, official. dependence' (Dudgeon v. The United Kingdom (1981): para. 17)
- sufficient knowledge and understanding of the reasonably foreseeable consequences of sexual intercourse;

- the capacity to choose whether or not to engage in sexual intercourse;

- the capacity to decide whether to give or withhold consent to sexual intercourse (and, where relevant, to communicate their choice to their spouse).

The Court noted that questions of capacity were 'always issue specific' and hence the question of whether someone has capacity to marry was not the same as whether that person has capacity to consent to sexual relations. In general, though, a sexual relationship was implicit in any marriage and hence someone who lacked capacity to consent to sexual relations would lack capacity to marry (but the converse was not necessarily true). Capacity to consent to sexual relations was issue specific and not partner specific.

The Court noted previous Article 8 jurisprudence regarding sexual relations (Box 3) and concluded that Article 8 protects two very different kinds of private life: the private life lived privately and kept hidden from the outside world and the private life lived in company with others or shared with the outside world.

Although M and her partner were not married, they had enjoyed a family life together because of the longevity of their relationship and each of them had a private life. The Court, in applying the principles of proportionality and necessity, needed to balance the conflicting issues that $M$ lacked capacity to decide where she should live or with whom she should associate, with the fact that she had been assessed as having capacity to enter into sexual relations, and her overall best interests.

The Court considered that the care plan proposals and restrictions from the local authority were disproportionate and would, if implemented, breach M's Article 8 rights. The judge assessed that the risks to her physical and mental health and safety were not such as to make it necessary for contact with her partner to be supervised as proposed by the authority (which would have interfered 'disproportionately' with her relationship with her partner). The authority was directed to modify their proposals such that $M$ continued to live in supported accommodation while facilitating her sexual relationship with her partner.

The principles from this case were core to another case in which a Muslim marriage ceremony (which took place via telephone between a 26 -year-old man with severe intellectual disabilities, who was in England at the time of the ceremony while the 
bride was in Bangladesh) was not valid under English law (Westminster City Council v. (1) IC (his litigation friend the Official Solicitor), (2) KC and (3) NNC [2007]).

\section{$M v$. (1) $B$, (2) $A$ and (3) $S$ (by her litigation friend the Official Solicitor) [2005]}

In this case, a local authority applied for declarations that a 23-year-old woman with a severe intellectual disability lacked capacity to marry and for the continuation of existing injunctions forbidding her parents from taking any steps in respect of any marriage to her or taking her abroad. (The authority was concerned that the parents wished to take her to Pakistan for an arranged marriage, which the family denied.)

The Court drew on previous jurisprudence in arriving at the test to be used in assessing capacity to enter into marriage (Sheffield City Council v. E (2004) - a case involving a young woman with hydrocephalus, spina bifida and intellectual disabilities, who met a convicted and imprisoned Schedule 1 sex offender). The Court opined that there were two aspects as to whether someone has the capacity to marry: (1) 'he or she must understand the nature of the marriage contract'; and (2) 'he or she must be mentally capable of understanding the duties and responsibilities that normally attach to marriage' (para. 68). The judgment expounded the duties and responsibilities that normally attach to marriage used in applying this test (Box 4).

The case involved evidence from psychiatrists, psychologists and social workers. It was common ground that the daughter lacked the requisite capacity to enter into marriage (the consultant psychiatrist applied the Re MB (Medical Treatment) [1997] test of capacity - a precursor to that now used under the Mental Capacity Act 2005: did the person comprehend, retain, use and weigh up the relevant information in arriving at a decision in failing the Sheffield test, above).

BOX 4 Duties and responsibilities normally attached to marriage

Marriage, whether civil or religious, is a contract, formally entered into. It confers on the parties the status of husband and wife, the essence of the contract being an agreement between a man and a woman to live together, and to love one another as husband and wife, to the exclusion of all others. It creates a relationship of mutual and reciprocal obligations, typically involving the sharing of a common home and a common domestic life and the right to enjoy each other's society, comfort and assistance.

(Mv. (1) B, (2) A and (3) S (by her litigation friend the Official Solicitor) [2005]: para. 132]
In clarifying that the daughter lacked capacity to enter into marriage, the Court granted an injunction preventing the parents from arranging a marriage for her 'safety and to prevent serious emotional and psychological harm' (para. 109) and upheld injunctions preventing them from taking her abroad. The Court opined that this was justified under Article 8 to protect her welfare and private life from being 'jeopardised' by her parents' potential actions in seeking to arrange marriage for her.

\section{Education}

\section{A v. Essex County Council [2008]}

This case concluded that an 18-month period when a severely disabled child was out of state education did not infringe his Article 8 rights. The child had severe intellectual disabilities, severe autism and epilepsy (10-15 brief seizures a day, despite medication). He had significant challenging behaviour characterised by self-harming such that he needed to wear arm splints and a helmet for protection. In January 2002, his school notified his parents that he would be removed from it because he was assessed as being a danger to other pupils and staff. The Council sought other schools appropriate to his needs (26 in all) but it was not until July 2003 that he commenced at a new school. He had received schoolwork when initially sent home (two boxes of educational activities - touch-books and bubbles) and during the ensuing 18 months had periods when speech and language therapy was provided and he attended a school twice weekly for individual (45 minute) sessions. It was accepted that during this period his challenging behaviour worsened.

The judgment found that Article 8 was not even engaged (no 'entry point' into Article 8(1) could be ascertained). Furthermore, a person of compulsory school age who has a special educational need has no right under the European Convention on Human Rights (Article 2 of the first protocol: the right to education) to be provided with an education of any particular type or in any particular school (the right was a "non-absolute right not to be denied access to the education system operating in the UK'). The judgment noted (para. 24) that the Convention was 'not a panacea for every ill' and the want of meaningful education provision at home, 'undesirable though it was', did not amount to a breach of Article 8 (even if Article 8 was assumed to be engaged).

\section{Discussion}

The above cases illustrate various ways in which Article 8 of the Human Rights Act has 
been used regarding people with an intellectual disability. They also demonstrate how Article 8 is implemented, based on the core principle of proportionality. Such Article 8 case law has in particular elucidated 'tests' for use in assessing capacity to enter into marriage $(M v$. (1) $B$, (2) $A$ and (3) $S$ (by her litigation friend the Official Solicitor) [2005]) and engage in sexual relations ( $X$ City Council v. $M B, N B$ and $M A B$ (by his litigation friend the Official Solicitor) [2006]) that can be applied in clinical practice. The Department of Health (2010) and the Joint Committee on Human Rights (2008) have also elucidated further diverse ways in which the Article 8 rights of people with intellectual disabilities may be infringed (Box 5).

In relation to the provision of appropriate community care, accommodation and day centres, the above cases demonstrate that consideration of Article 8 is vital and even core to any such assessment processes: Article 8(1) will almost always be engaged and need justification under Article 8(2). An individual may well have been resident in or attended a placement for many years, and although this does not legally mean a 'home for life' (as may have been assumed by the individual and/or family in long-term placements), Article 8 should be central to decisions in moving a person from a long-term placement even where the primary reason is financial (for example, to close a facility to reinvest in community resources). Such decisions, although they may tend to appear to side more with organisational needs rather than individual needs, must nevertheless have Article 8 analysis underpinning the process. Failure to do

\section{BOX 5 Ways in which Article 8 rights of people with intellectual disabilities may be infringed}

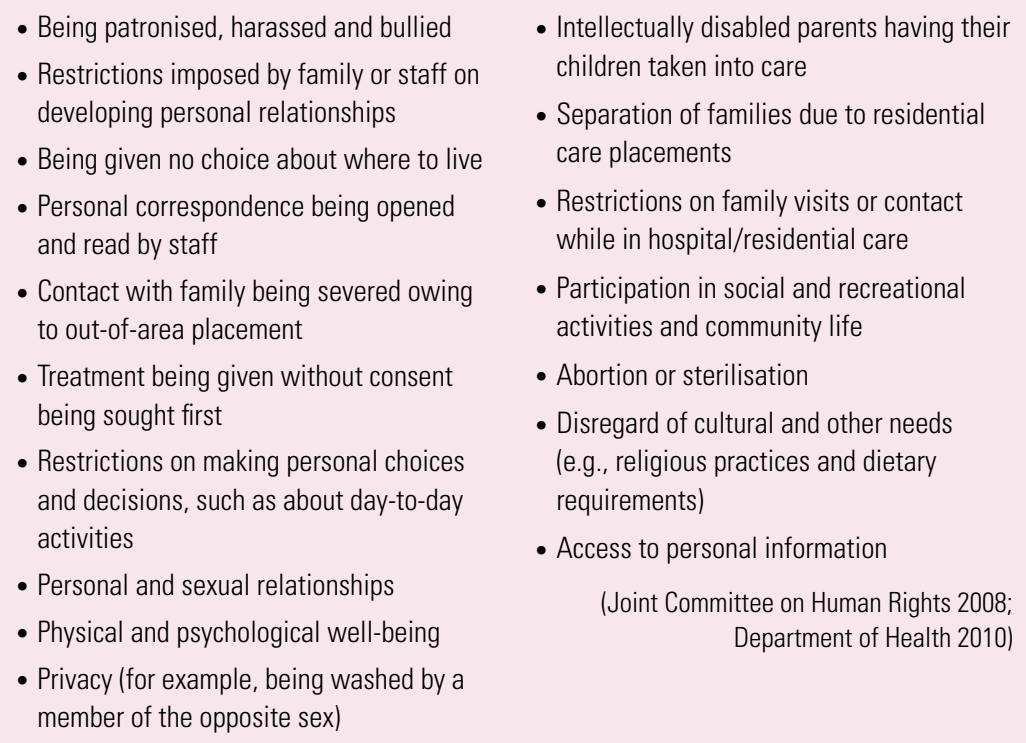

so would almost certainly be grounds for anyone affected to successfully challenge a decision against them.

Regarding the Human Rights Act (and the European Convention on Human Rights) and healthcare, Article 8 is often considered in conjunction with Article 3 (Curtice 2009b). Article 3 affords protection, to both capacitous and incapacitous people, from inhuman and degrading treatment and may be important when considering medical (mal)treatment, as has previously been discussed in this journal (Curtice 2008). Importantly, emerging case law has shown that for people who are deprived of their liberty, there is an obligation to provide both requisite standards of medical care (Pilcic v. Croatia (2008); Musial v. Poland (2009)) and appropriate conditions of detention (Dybeku v. Albania (2007)) - failure to do so in both of these areas could lead to a breach of Article 3 and/or Article 8.

A case involving Article 5 (the right to liberty) and a person with a severe intellectual disability and autism (HL v. The United Kingdom [2004]) has arguably led to one of the most important developments in recent decades in mental health legislation, whereby the Mental Capacity Act 2005 was amended in England and Wales to include the deprivation of liberty safeguards to plug the infamous 'Bournewood gap' ( $R v$ Bournewood Community and Mental Health NHS Trust, ex parte $L$ [1998]).

But what of the future of human rights protection for people with an intellectual disability? Reports in recent years have described and brought to the fore severe deficiencies in the care of people of all ages with intellectual disabilities (Healthcare Commission 2006; Disability Rights Commission 2006; 2007; Mencap 2007; Joint Committee on Human Rights 2008; Parliamentary and Health Service Ombudsman 2009). The Joint Committee on Human Rights report notes that such deficiencies, at both individual and collective organisational levels, will certainly have violated various Human Rights Act Articles. The protection afforded by the Human Rights Act may be enhanced in the UK by continued and improved recognition and monitoring of human rights issues for people with intellectual disabilities, coupled with improved education for them and their carers (for example, A Guide to the Human Rights Act - A Booklet for People with Learning Disabilities (Ministry of Justice 2008)) and training for organisations and service providers (Department of Health 2010). The Disability Discrimination Act 2005 will help to enhance such issues underpinned by the 'disability equality duty' embedded at its core. 
The Care Quality Commission (2009) has published a 5-year plan 'underpinned by the principles of equalities and human rights' to drive up standards of care for people with an intellectual disability in England. In 2009, the UK ratified the UN Disability Rights Convention and, although not yet incorporated into domestic legislation, it is potentially highly influential. This is because domestic Courts and the European Court of Human Rights regularly refer to such international human rights treaties (similarly, the United Nations Convention on the Rights of the Child) to assist in the interpretation of the European Convention on Human Rights (and hence the Human Rights Act) in relation to disability issues.

It is hoped that these and other similar developments at local, national, European (for example, the Mental Disability Advocacy Centre) and international levels will drive up standards of care for people of all ages with an intellectual disability. This is vital because, as the Joint Committee on Human Rights (2008) poignantly yet saliently commented, it is disappointing that almost 10 years after the introduction of the Human Rights Act the 'evidence received convinces us that we need to emphasise that adults with learning disabilities have the same human rights as everyone else; and that they are entitled to freedom, respect, equality, dignity and autonomy in their everyday lives' (para. 44).

\section{References}

Care Quality Commission (2009) Strategic Plan 2010-2015 - Position Statement and Action Plan for Learning Disability. Care Quality Commission (http://www.cqc.org.uk/_db/_documents/COC_learning_ disability_strat_plan_2010-15_201001125203.pdf).

Curtice M (2008) Article 3 of the Human Rights Act 1998: implications for clinical practice. Advances in Psychiatric Treatment. 14: 389-97.

Curtice M (2009a) Article 8 of the Human Rights Act 1998: implications for clinical practice. Advances in Psychiatric Treatment. 15: 23-31.

Curtice M (2009b) Medical treatment under Part IV of the Mental Health Act 1983 and the Human Rights Act 1998: review of Article 3 and 8 case law. Psychiatric Bulletin 33: 111-5.

Curtice M, Sandford J (2009c) Article 8 of the Human Rights Act 1998. A review of case law related to forensic psychiatry and prisoners in the United Kingdom. Journal of the American Academy of Psychiatry and the Law. 37: 232-8.

Department of Health (2010) Human Rights Training Materials and Human Rights Resources. Department of Health (http://www.dh.gov.uk/en/ Publicationsandstatistics/Publications/PublicationsPolicyAndGuidance/ DH_115174)

Disability Rights Commission (2006) Equal Treatment: Closing the Gap. A Formal Investigation into Physical Health Inequalities Experienced by People with Learning Disabilities and/or Mental Health Problems. Disability Rights Commission (http://www.leeds.ac.uk/disabilitystudies/archiveuk/DRC/Health\%20FI\%20main.pdf).

Disability Rights Commission (2007) Equal Treatment: Closing the Gap - One Year On. Report of the Reconvened Formal Inquiry Panel of the DRC's Formal Investigation into the Inequalities in Physical Health Experienced by People with Mental Health Problems and Learning
Disabilities. Disability Rights Commission (http://www.leeds.ac.uk/ disability-studies/archiveuk/DRC/closing_the_gap_fi.pdf).

Healthcare Commission (2006) Joint Investigation into the Provision of Services for People with Learning Disabilities at Cornwall Partnership NHS Trust. Healthcare Commission (http://www.cqc.org.uk/_db/_ documents/cornwall_investigation_report.pdf).

Joint Committee on Human Rights (2008) A Life Like Any Other? Human Rights of Adults with Learning Disabilities. Seventh Report of Session 2007-08. HL Paper 40-l; HC 73-I. TSO (The Stationery Office).

Mencap (2007) Death by Indifference. Mencap (http://www.mencap. org.uk/document.asp?id=284).

Ministry of Justice (2008) A Guide to the Human Rights Act - A Booklet for People with Learning Disabilities. Ministry of Justice (http://www. justice.gov.uk/guidance/docs/human-rights-act-learning-disabilities. pdf).

Parliamentary and Health Service Ombudsman (2009) Six Lives. The Provision of Public Services to People with Learning Disabilities. Part One.Overview and Summary Investigation Reports. Second Report. Session 2008-2009. Presented to Parliament Pursuant to Section 14(4) of the Health Service Commissioners Act 1993. HC 203-1. TSO (The Stationery Office.

A v. Essex County Council [2008] EWCA Civ 364.

Bernard v. London Borough of Enfield [2002] EWHC 2282 (Admin)

(1) $\mathrm{CH}$ (by the Official Solicitor as litigation friend) and (2) MH (by the Official Solicitor as litigation friend) v. Sutton \& Merton Primary Care Trust [2004] EWHC 2984 (Admin).

Dudgeon v. The United Kingdom (1981) 4 EHRR 149.

Dybeku v. Albania (2007) European Court of Human Rights Application no 41153/06 18th December.

HL v. The United Kingdom [2004] 40 EHRR 761.

Katie Collins v. The United Kingdom (2002) European Court of Human Rights Application no 11909/02 15th October.

Local Authority X v. (1) MM (by her litigation friend the Official Solicitor) (2) KM [2007] EWHC 2003 (Fam).

$M v$. (1) $B$, (2) $A$ and (3) $S$ (by her litigation friend the Official Solicitor) [2005] EWHC 1681 (Fam).

Markcx v. Belgium [1979] 2 EHRR 330.

Musiał v. Poland (2009) European Court of Human Rights Application no 28300/06 20th January.

Pilcic v. Croatia (2008) European Court of Human Rights Application no 33138/06 17th January.

Pretty v. The United Kingdom (2003) 35 EHRR 1.

Rachel Gunter (by her litigation friend and father Edwin Gunter) v. South Western Staffordshire Primary Care Trust [2005] EWHC 1894 (Admin).

$R$ (on the application of (1) $A$, (2) $B$ (by their litigation friend the Official Solicitor), (3) $X$ and (4) Y) v. East Sussex County Council \& the Disability Rights Commission (interested party) [2003] EWHC 167 Admin.

$R$ (on the application of Hughes) v. Liverpool City Council [2005] EWHC 428 (Admin)

$R$ (on the application of $J$ and others) v. Southend Borough Council [2005] EWHC 3457 (Admin).

$R v$ Bournewood Community and Mental Health NHS Trust, ex parte $L$ [1998] 3 All ER 289

Re MB (Medical Treatment) [1997] 2 FLR 426.

Sheffield City Council v. E (2004) EWHC 2808 (Fam), (2005) 326 (Fam)

Westminster City Council v. (1) IC (his litigation friend the Official Solicitor), (2) KC and (3) NNC [2007] EWHC 3096 (Fam).

$X$ and $Y v$. The Netherlands (1985) 8 EHRR 235.

$X$ City Council v. MB, NB and MAB (by his litigation friend the Official Solicitor) [2006] EWHC 168 (Fam)

\section{MCQ answers \\ 1 e 2 d 3 e 4 b 5 e}




\section{MCQs}

Select the single best option for each question stem

1 The following is true:

a the Human Rights Act 1998 incorporates into UK law all of the rights and freedoms set out in the European Convention on Human Rights

b Article 8 is an absolute right

c Article 8 provides the right to respect for private and family life only

d Article 8 consists of three paragraphs

e Article 8 is often considered in conjunction with Article 3.

2 Regarding Article 8 and accommodation:

a a 'home for life' implies that the needs of individuals do not have to be met appropriately

b Section 20 of the National Assistance Act 1948 encompasses the duty of local authorities to provide accommodation

c a breach of duty under the National Assistance Act 1948 will always result in a breach of Article 8 d a 'home for life' does not necessarily mean at a particular hospital or place of residence

e Article 8 requires the state to provide every citizen with a house.

3 Regarding sexual relations and Article 8:

a Article 8 does not recognise that sexual activity is a most intimate aspect of private life

b sexual activity does not involve fundamental values and essential aspects of private life

c private life does not encompass choice about personal and sexual relationships with others

d Article 8 does not require respect for an individual's sexual activities

e states may be under a positive duty to prevent unwanted or inappropriate sexual attention, especially for those who lack capacity.

4 The following is true:

a the European Convention on Human Rights affords an absolute right to be provided with an education of any particular type or in any particular school b there are negative and positive obligations inherent in effective respect for private or family life

c human dignity is specifically mentioned in the European Convention on Human Rights

d capacity to consent to sexual relations is partner specific

e someone who lacks capacity to consent to sexual relations will have the capacity to marry.

5 Regarding Article 8:

a it only protects the private life lived privately and kept hidden from the outside world

b it protects only the private life lived in company with others or shared with the outside world

c the right to respect for one's physical and psychological integrity can be analysed into three distinct, equally important concepts

$\mathrm{d}$ it may require public authorities to take positive measures only to secure respect for private or family life

e there can in some circumstances be competing Article 8 rights between individuals. 